\title{
Copepod feeding patterns before and during a spring bloom in Bedford Basin, Nova Scotia
}

\author{
E. J. H. Head, L. R. Harris \\ Department of Fisheries and Oceans, Biological Sciences Branch, Bediord Institute of Oceanography, PO Box 1006, Dartmouth,
} Nova Scotia B2Y 4A2, Canada

\begin{abstract}
Samples of zooplankton were collected at frequent intervals in the top $30 \mathrm{~m}$ of Bedford Basin over one $48 \mathrm{~h}$ and two $24 \mathrm{~h}$ sampling periods in February, early March and late March, 1986. Measurements of gut pigment content showed that Pseudocalanus sp. and Acartia sp. in early March had bimodal diurnal feeding rhythms, with peaks in activity at around dawn and dusk, while in February and in late March they appeared to be feeding more-or-less continuously. The sampling series covered the period of the algal spring bloom and maximal ambient chlorophyll concentrations measured in the top $30 \mathrm{~m}$ increased from $3.5 \mu \mathrm{g} \mathrm{l^{-1 }}$ in February to $21.0 \mu \mathrm{g} \mathrm{l^{-1 }}$ in early March, decreasing to $12.8 \mu \mathrm{g}$ $1^{-1}$ in late March. We suggest that the diurnal feeding rhythms found in early March resulted from an imbalance between the ability of copepods to ingest food, which would have incroased rapidly during the early spring bloom as phytoplankton levels increased, and their caparity to digest it. Later on in the bloom period, it seems that ingestion and digestion rates became balanced again so that diumal rhythms were not apparent in late March. Such an effect may have been due to adaptive processes occurring in the digestive physiology of the copepods as the result of exposure to high food concentrations, or perhaps to changes in the composition of the food itself. Related laboratory experiments showed that hunger and light intensity both affected feeding behavior in vitro in a way consistent with that observed in situ.
\end{abstract}

\section{INTRODUCTION}

The relationship between diurnal vertical migration and feeding activity in zooplankton has long been a subject of interest to aquatic ecologists and zooplankton physiologists. It has been suggested that copepods migrate vertically to avoid visual predation (Zaret \& Suffern 1976, Fancett \& Kimmerer 1985, Gliwicz 1986) or perhaps to decrease their metabolic rates during the day by swimming down through the thermocline to relatively colder water after feeding in warmer nearsurface waters (McLaren 1963). The observation that nocturnal feeding and nocturnal vertical migration were positively correlated led Gauld (1953) to hypothesize that one was the result of the other, so that animals moving up by night into the phytoplanktonrich surface layers would feed more actively. While this hypothesis has been supported by many field studies (Gauld 1953, Daro 1980, Simard et al. 1985, Lampert \& Taylor 1985), there is a growing body of evidence which suggests that it is not always the case. Several authors have demonstrated noctural feeding in the absence of diurnal migration (Mackas \& Bohrer 1976 ,
Boyd et al. 1980, Hayward 1980, Nicolajsen et al. 1983, Head et al. 1985) and others have found it in situations where chlorophyll a was vertically homogeneous (Baars \& Oosterhuis 1984, Mayzaud et al. 1984, Daro 1985, Stearns 1986). McAllister (1970) suggested that nocturnal feeding might in itself be advantageous if zooplankton were to concentrate their feeding early in the evening when they could utlize the maximal amount of photosynthetically fixed energy per algal cell, before appreciable phytoplankton respiration would have occurred. In support of this idea Head et al. (1985) showed that nocturnal feeding activity of nonmigratory Arctic copepods started at ambient light intensities close to the compensation intensity of the phytoplankton.

Although direct tests of the hypotheses concerning either nocturnal vertical migration or nocturnal feeding and their interrelationships have been attempted in several cases (Haney \& Hall 1975, Mackas \& Bohrer 1976, Dagg \& Wyman 1983, Daro 1985, Dagg 1985) none of the theories can be regarded as proven. Much useful information, however, has been obtained by studying how the processes are controlled. Light inten- 
sity is the most obvious factor governing nocturnal vertical migration from day-to-day Indeed it has a direct effect on copepod swimming activity in the laboratory (Hardy \& Bainbridge 1954, Stearns \& Forward 1984) and its effect in the field has long been surmised from day and night observations of zooplankton vertical distribution (e.g. Cushing 1951, Banse 1964, Longhurst 1985). Patterns of vertical migratory behavior may vary with developmental stage of a particular species, such that later stages perform more extensive migrations (Huntley \& Brooks 1982, Williams \& Conway 1984) or with ambient food levels such that when food concentration is low, vertical migration is reduced and zooplankton spend longer nearer the surface apparently in order to extend their daily feeding period (Bohrer 1980, Huntley \& Brooks 1982, Dagg 1985). Nocturnal feeding may still be observed, however, in the absence of vertical migration, even when chlorophyll concentrations are low (Hayward 1980).

Studies of the factors that control nocturnal or intermittent feeding directly have been somewhat limited. Head (1986) and Stearns (1986) have shown that light intensity affects copepod feeding activity in vitro and Head et al. (1985) and Stearns (1986) have suggested that it may provide the cue for the timing of the onset of nocturnal feeding in situ. It is also possible that an endogenous component is involved so that a higher feeding activity occurs at night than during the day at a given light intensity (Head 1986, Stearns 1986). The effects of developmental stage or food availability on diurnal feeding activity within a non-migratory population have not been described as yet, although because of their effects on vertical migration, one might suspect them of being directly involved. Here we have looked for differences in diurnal feeding behavior in situ of copepods from Bedford Basin in February when food concentrations were relatively low $\left(<4 \mu \mathrm{g} \mathrm{chla} \mathrm{l^{-1 }}\right)$, in early March when the spring bloom was near its peak

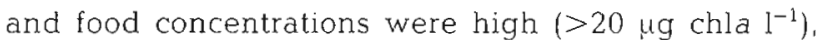
and in late March when the bloom was sinking out. We also examined the effects of light and time of day on ingestion rates of copepods collected in February and mid-March in vitro, to see if they were consistent with the observed in situ behavior.

\section{MATERIAL AND METHODS}

Field sampling for the diel series. Zooplankton and water samples were collected at the compass buoy in Bedford Basin, Nova Scotia, Canada, during a 48 h period on 3-5 Mar and two $24 \mathrm{~h}$ periods on 12-13 Feb and 24-25 Mar 1986. Zooplankton samples were collected using a $0.75 \mathrm{~m}$ diameter ring net of $233 \mathrm{l} \mathrm{m}$ mesh towed vertically from 0 to $30 \mathrm{~m}$. Samples for species identification, enumeration and dry weight analysis were collected both day and night and were preserved in $5 \%$ formalin. Samples for gut pigment analysis were collected at hourly intervals. These were rinsed rapidly with filtered seawater on a $233 \mu \mathrm{m}$ mesh screen and then filtered onto sharkskin filter paper and frozen for subsequent analysis in the laboratory.

Water samples were collected at midday and midnight for measurement of particulate chlorophyll concentration at depths of $0,5,10,20$ and $30 \mathrm{~m}$. Samples $(100 \mathrm{ml})$ were filtered onto Whatman GFF glass fibre filters and frozen for subsequent laboratory analyses.

Photosynthetically active incident light radiation (400 to $700 \mathrm{~nm}$ ) was continuously recorded over $1 \mathrm{~h}$ time intervals using a LI-COR LI-190SB Quantum Sensor and a LI 550 Printing Integrator

During the February and the 24-25 March diurnal sampling series gut clearance rates were measured for Pseudocalanus sp. Which were collected as for the gut pigment sampling series, quickly rinsed and placed in $8 \mathrm{l}$ carboys filled with filtered seawater at a concentration of ca 200 ind $1^{-1}$. Subsamples (ca $200 \mathrm{ml}$ ) of water and copepods were taken at timed intervals for the next $3 \mathrm{~h}$ and the copepods filtered on to sharkskin filters and frozen for subsequent analysis. Between sampling times the carboys were incubated in the sea on lines attached to the sampling vessel. Two gut clearance experiments were run during the 12-13 Feb sampling series, one at midnight and one at $0600 \mathrm{~h}$ and one experiment was run during the 24-25 Mar diurnal sampling series at $2000 \mathrm{~h}$. During the 3-5 Mar sampling period we could not measure gut clearance rates since it proved impossible to separate copepods and algae at the high algal concentrations which were present.

Laboratory experiments. Copepods were collected at between 0900 and $1000 \mathrm{~h}$ in horizontal tows from between 10 and $15 \mathrm{~m}$ depth during February and March using a $233 \mu \mathrm{m}$ mesh net. They were placed in surface seawater and transported back to the laboratory. In March surface seawater (ca 40 l) with a high concentration of phytoplankton was also collected for use in the experiments. In the laboratory the copepods were rinsed with filtered seawater of appropriate in situ temperature and divided equally into 2 darkened 81 plastic carboys, containing filtered seawater. The concentration of copepods was between 1000 and 2000 ind $1^{-1}$ in these carboys, which were then placed into an incubator of appropriate temperature. After about $1 \mathrm{~h}$. at about $1300 \mathrm{~h}$, one of the carboys was removed from the incubator for use in the so-called 'daytime' experiments. Copepods were concentrated into 7 batches of about $150 \mathrm{ml}$ (ca 2000 individuals per batch), 6 of which were added to 6 plastics carboys containing 51 of either Chaetoceros gracilis culture of appropriately adjusted 
concentration (February) or surface seawater containing natural algae at the natural concentration (12 and 14-15 Mar). The seventh sample was preserved (5\% formalin) for species identification and enumeration and dry weight determination. Three of the carboys were darkened and 3 were not. Then and at timed intervals for $3 \mathrm{~h}$ afterwards, subsamples $(250 \mathrm{ml})$ of copepods and water were taken from each carboy. The copepods were screened off on a $233 \mu \mathrm{m}$ mesh, rinsed with filtered seawater and filtered onto sharkskin filters and frozen for subsequent gut pigment analysis. Initially, and at hourly intervals afterwards, samples of the screened water $(100 \mathrm{ml})$ were filtered onto GFF glass fibre filters for measurement of the concentration of particulate chlorophyll. Between sampling times the carboys were kept in a temperature-controlled incubator fitted with cold fluorescent lights, and set at close to in situ water temperature. Light intensity was measured for each series of experiments using a Biospheri$\mathrm{cal}^{\circledR}$ QSL $1004 \pi$ light sensor. For the so-called nighttime' experiments the second half of the morning's sample was treated as the daytime sample had been. The incubations were set up at about $1900 \mathrm{~h}$. In one experiment, carried out on 14 and 15 Mar, zooplankton and water were collected at about $1500 \mathrm{~h}$ and light and dark incubations were carried out at $1900 \mathrm{~h}$ that evening and at $1300 \mathrm{~h}$ the following day. Copepods were treated as described for the regular experiments so that the second batch was left as before without food, this time for a total period of about $22 \mathrm{~h}$.

Analysis of samples. For gut pigment analysis, samples were sorted under a dissecting microscope, and treated as described by Mackas \& Bohrer (1976). For the diurnal series 3 batches of between 30 and 50 specimens were taken per time point for Pseudocalanus sp. For Acartia sp. 3 batches of between about 20 and 30 specimens per time point were analysed. For the laboratory experiments one sample of between 20 and 50 specimens per time point per carboy was analysed, except in the case of Acartia sp. on 12 Mar, when the subsamples from all 3 light or all 3 dark carboys were combined to give one sample containing ca 20 to 30 specimens for each time point.

For the measurement of particulate chlorophyll, samples on GFF filters were extracted with $90 \%$ acetone overnight at $-20^{\circ} \mathrm{C}$, and analysed by the fluorescence method (Holm-Hansen et al. 1965).

\section{RESULTS}

Chlorophyll concentrations did not change much at the different sampling depths during any of the sampling series (Fig. 1). In February there was a subsurface $(10 \mathrm{~m})$ peak of about $3.5 \mu \mathrm{g} \mathrm{l^{-1 }}$ chlorophyll and the

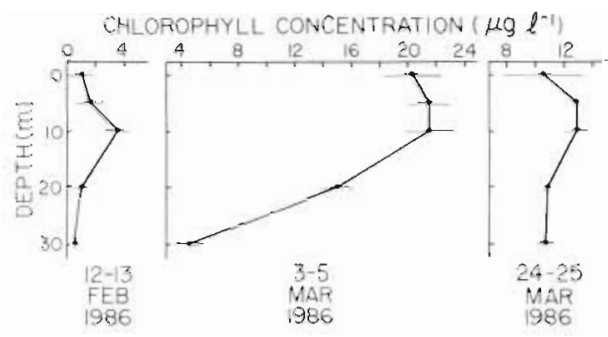

Fig. 1. Particulate chlorophyll profiles in the $10 \mathrm{p} 30 \mathrm{~m}$ for 12-13 Feb; 3-5 Mar and 24-25 Mar 1986. Results are plotted as means of the profiles obtained throughout each sampling period with standard deviations for 12-13 Feb and 3-5 Mar and the range of only 2 values obtained on 24-25 Mar

temperature in the top $30 \mathrm{~m}$ was a uniform $0^{\circ} \mathrm{C}$ $\left( \pm 0.5 \mathrm{C}^{\circ}\right)$. In early March the spring bloom was occurring with chlorophyll concentrations of over $20 \mu \mathrm{g}^{-1}$ in the top $10 \mathrm{~m}$ dropping to about $15 \mu \mathrm{g} \mathrm{l}^{-1}$ at $20 \mathrm{~m}$, and $4.5 \mathrm{\mu g} \mathrm{l}^{-1}$ at $30 \mathrm{~m}$. The temperature was $1^{\circ} \mathrm{C}\left( \pm 0.3 \mathrm{C}^{\circ}\right)$ throughout the top $30 \mathrm{~m}$. By late March the bloom was beginning to die and sink out, so that the chlorophyll concentration was about $10 \mu \mathrm{g} \mathrm{I}^{-1}$ throughout the top $30 \mathrm{~m}$, while the temperature varied from about $2.5^{\circ} \mathrm{C}$ at the surface to $0.5^{\circ} \mathrm{C}$ at $30 \mathrm{~m}$

In February Pseudocalanus sp. and Acartia sp. were the most abundant species in the top $30 \mathrm{~m}$ (Table 1 ). The differences in their day and night abundances were probably not significant. During 3-4 Mar the abundance of Pseudocalanus sp. was not very different from that seen in February although that of Acartia sp. was somewhat reduced. There were no consistent differences in zooplankton concentration or stage distribution in Pseudocalanus sp. in the top $30 \mathrm{~m}$ depth range from day to night (Table 1). On 24-25 Mar however, the stage distribution of the Pseudocalanus sp. showed a substantial decrease in the percentage of females present and an increase in numbers of younger stages (Table 1). Abundance of both Pseudocalanus sp. and Acartia sp. were somewhat higher than on the previous sampling dates and apparently almost doubled at night, suggesting that some vertical migration may have been occurring.

In the February diurnal series, although both of the species studied exhibited variations in gut pigment levels during the $24 \mathrm{~h}$ sampling series (Fig. 2), neither showed evidence of diel periodicity. In the 3-5 Mar diurnal series, there were regular variations in gut pigment content in both Pseudocalanus sp. and Acartia sp., with highest levels occurring at dawn and dusk (Fig. 3). By the 24-25 Mar series, however, there were again no regular variations in gut pigment content in either species (Fig. 4). Hourly ingestion rates were calculated for Pseudocalanus sp. for the February and late March series, using the expression

$$
\mathrm{I}=\frac{\mathrm{dC}}{\mathrm{dt}}+\mathrm{kC}
$$


Table 1. Concentrations of Pseudocalanus sp. and Acartia sp. and stage distribution of Pseudocalanus $\mathrm{sp}$. in the 0 to $30 \mathrm{~m}$ depth range in Bedford Basin during spring 1986

\begin{tabular}{|c|c|c|c|c|c|c|c|c|c|c|c|c|}
\hline \multirow{2}{*}{$\begin{array}{l}\text { Date } \\
(1986)\end{array}$} & \multirow{2}{*}{$\begin{array}{l}\text { Time } \\
\text { (h) }\end{array}$} & \multicolumn{7}{|c|}{ Pseudocalanus $\mathrm{sp}$. stages \% composition } & \multicolumn{2}{|c|}{ Pseudocalanus sp. } & \multicolumn{2}{|c|}{ Acartia sp. } \\
\hline & & VIP & VI $\delta$ & $\vee Q$ & Vò & IV & III & II & $\begin{array}{l}\text { Abundance } \\
\text { (ind } \mathrm{m}^{-3} \text { ) }\end{array}$ & $\begin{array}{l}\text { Av. dry wt. } \\
\left.\text { (ug ind }{ }^{-1}\right)\end{array}$ & $\begin{array}{l}\text { Abundance } \\
\text { (ind } \mathrm{m}^{-3} \text { ) }\end{array}$ & $\begin{array}{l}\text { Av. dry wt. } \\
\left(\mu \mathrm{g} \mathrm{ind}^{-1}\right)\end{array}$ \\
\hline 12 Feb & 1200 & 26 & 4 & 12 & 11 & 18 & 20 & 8 & 889 & 3.3 & 174 & 3.0 \\
\hline 12 Feb & 2400 & 32 & 7 & 7 & 6 & 22 & 15 & 11 & 633 & 6.7 & 67 & 4.8 \\
\hline 3 Mar & 1300 & 31 & 8 & 19 & 19 & 18 & 5 & 1 & 139 & 13.1 & 17 & 5.1 \\
\hline 3 Mar & 2315 & 23 & 3 & 10 & 14 & 23 & 20 & 7 & 843 & 9.9 & 65 & 4.9 \\
\hline $4 \mathrm{Mar}$ & 1200 & 37 & 6 & 18 & 21 & 14 & 3 & 1 & 310 & 15.2 & 31 & 5.7 \\
\hline $4 \mathrm{Mar}$ & 2310 & 26 & 6 & 16 & 18 & 19 & 11 & 4 & 280 & 12.3 & 13 & 5.0 \\
\hline $24 \mathrm{Mar}$ & 1200 & 14 & 5 & 11 & 14 & 16 & 19 & 20 & 2105 & 7.5 & 299 & 3.2 \\
\hline $25 \mathrm{Mar}$ & 0400 & 14 & 7 & 10 & 13 & 20 & 24 & 9 & 3980 & 11.0 & 723 & 3.0 \\
\hline
\end{tabular}
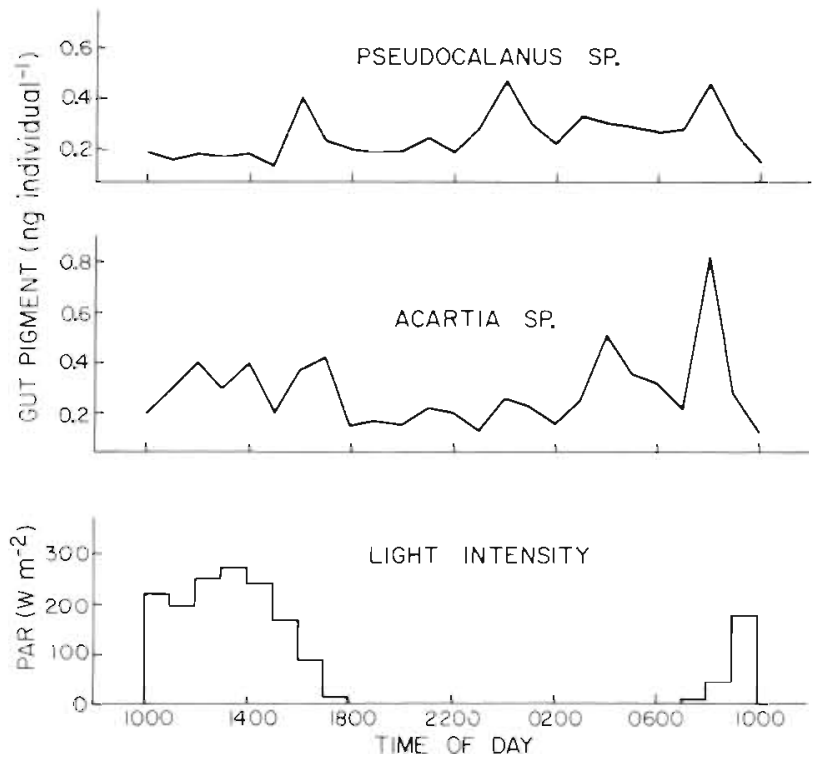

Fig. 2. Pseudocalanus sp. and Acartia sp. Diel variations of the levels of chlorophyll and phaeopigment and incident light intensity (photosynthetically active radiation, PAR) on 12-13 Feb 1986. The means only 3 of sample values are plotted for clarity. Standard deviations were usually $<30 \%$ and $<40 \%$ of the means for Pseudocalanus and Acartia, respectively

where $\mathrm{I}=$ ingestion rate; $\mathrm{C}=$ gut pigment concentration; and $\mathrm{k}=$ defecation rate constant (Head 1986). Values of $0.26 \mathrm{~h}^{-1}$ and $1.19 \mathrm{~h}^{-1}$ were used for $\mathrm{k}$ (Table 2). These were calculated over the first hour of the gut clearance experiments in February and first $2 \mathrm{~h}$ in March, since these were the periods over which the semi-logarithmic plots were linear (Kiørboe \& Tiselius 1987. Head et al. unpubl.) Hourly ingestion rates showed patterns very similar to those found for gut pigment levels. Estimates of the maximum and minimum rates, and filtration rates derived from them by dividing them by the concentraion of chlorophyll at the chlorophyll maximum, are shown in Table 3, along with daily ingestion rates which were calculated by summing the hourly rates over $24 \mathrm{~h}$.

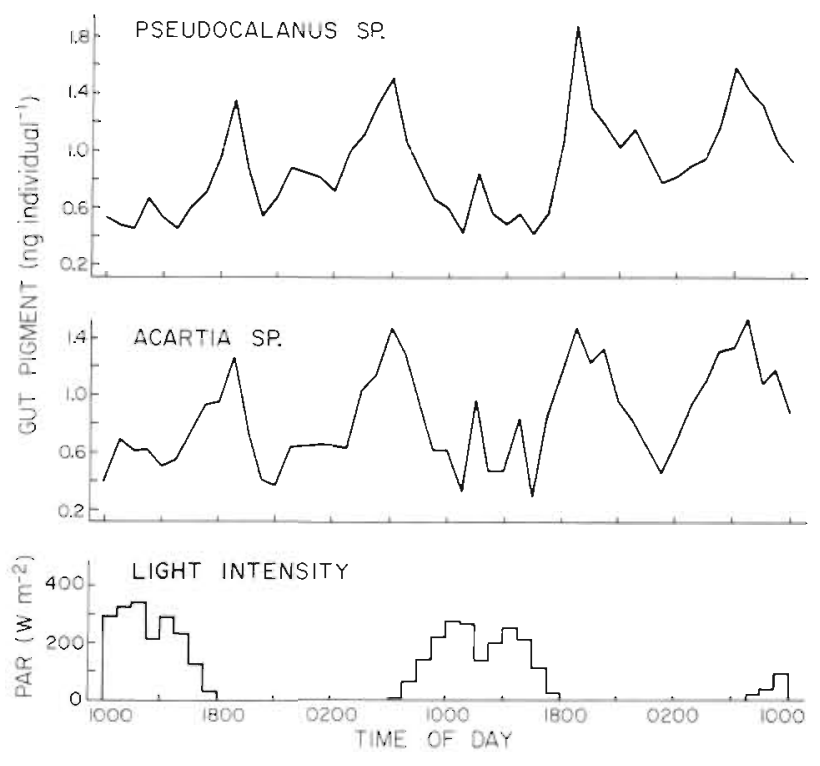

Fig. 3. Pseudodalanus sp. and Acartia sp. Diel variations of the levels of chiorophyll and phaeopigment and incident light intensity (photosynthetically active radiaton, PAR) on 3-5 Mar 1986. The means only of 3 samples values are plotted for clarity. Standard deviations were usually $<30 \%$ and $<40 \%$ of the means for Pseudocalanus and Acartia, respectively

In the laboratory experiments the stage distributions of Pseudocalanus sp. were quite similar on all 3 occasions (Table 4), while their concentrations were more varied, as were the effects of their grazing on the level of particulate chlorophyll in the experimental bottles over the course of the $3 \mathrm{~h}$ incubations (Table 5). For these experiments 2 features of the time course incubations will be described. In the first 15 min of each incubation gut pigment uptake was more-or-less linear providing an 'initial' rate (Fig. 5 to 8). In the final 90 min the level of gut pigment was more-or-less constant giving an 'equilibrium rate' at which ingestion rate was approximately equal to defecation rate.

In February incubation temperature was $4{ }^{\circ} \mathrm{C}$ and light intensity was about $7 \mathrm{~W} \mathrm{~m}^{-2}$ in the light incuba- 
tions. For Pseudocalanus sp. initial rates in Incubations $A, B$ and $C$ were not distinguishable $(p>0.05)$, although that in Incubation $D$ was different from all 3 others $(p<0.05)$ (Fig. 5). Equilibrium rates in Incubations $B, C$ and $D$ were not significantly different from each other (Student's t-test $p>0.05$ ) whereas that in Incubation $A$ was significantly lower $(p<0.05)$. In the March experiments temperature was between 0 and $2{ }^{\circ} \mathrm{C}$ and light intensity was about $6 \mathrm{~W} \mathrm{~m}^{-2}$ in Incubations A and C. For Pseudocalanus on 12 Mar (Fig. 6), analysis of variance showed that the only pair of initial rates that were not significantly different from each other at the $p<0.05$ level were in Incubations $C$ and $D$. All equilibrium rates were different from each other at the $\mathrm{p}<0.05$ level. Results for Acartia sp. (Fig. 7) were obtained by pooling specimens from all 3 light or dark carboys per sampling point to give a single sample per time point. For this reason statistical analysis was not applied although it is obvious that daytime initial rates

Table 2. Pseudocalanus sp. Summary of data for gut clearance experiments in spring 1986. Data were analysed according to the equation $\ln \mathrm{C}=\ln \mathrm{C}_{\mathrm{o}}-\mathrm{kt}$ where $\mathrm{C}=$ gut pigment level at time $t_{;} C_{0}=$ initial gut pigment concentration; $\mathrm{k}=$ defecation rate constant

\begin{tabular}{|llll|}
\hline $\begin{array}{l}\text { Date } \\
\text { (1986) }\end{array}$ & \multicolumn{1}{c}{$\ln \mathrm{C}=\ln \mathrm{C}_{\mathrm{o}}-\mathrm{kt}$} & $\mathrm{r}^{2}$ & $\mathrm{k}\left(\mathrm{h}^{-1}\right)$ \\
\hline $12 \mathrm{Feb}$ & $\ln \mathrm{C}=\ln (0.30)-0.38 \mathrm{t}$ & 0.62 & 0.26 \\
$13 \mathrm{Feb}$ & $\ln \mathrm{C}=\ln (0.1)-0.263 \mathrm{t}$ & $0.73^{\circ}$ & \\
$24 \mathrm{Mar}$ & $\ln \mathrm{C}=\ln (0.28)-1.194 \mathrm{t}$ & 0.87 & 1.19 \\
$\mathrm{p}<0.05 ; \cdots \mathrm{p}<0.01$ & & \\
\hline
\end{tabular}

were lower than night-time ones. The subsequent parts of Incubations C and D, however, showed that Acartia fed rapidly for only about $1 \mathrm{~h}$, before returning to a low rate. In this instance comparison of equilibrium rates is inappropriate. In the final 'reverse' experiment (Fig. 8), where the night-time incubations preceeded the day-
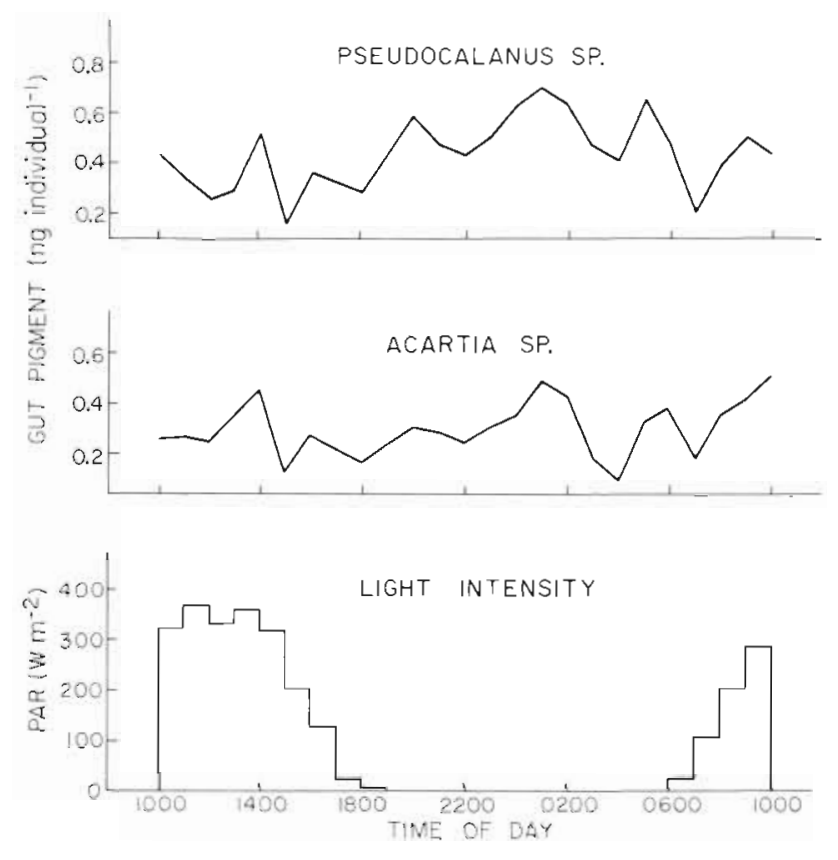

Fig. 4. Pseudocalanus sp. and Acartia sp. Diel variations of the levels of chlorophyll and phaeopigment and incident light intensity (photosynthetically active radiaton, PAR) on 24-25 Mar 1986. The means only of 3 sample values are plotted for clarity. Standard deviations were usually $<30 \%$ and $<40 \%$ of the means for Pseudocalanus and Acartia, respectively

Table 3. Pseudocalanus sp. Comparison of maximum and minimum hourly chlorophyll ingestion rates recorded during spring 1986, as found in the sampling series carried out in Bedford Basin, calculated from the expression $\mathrm{I}=\mathrm{dC} / \mathrm{dt}+\mathrm{kC}$

\begin{tabular}{|c|c|c|c|c|c|c|}
\hline Date & $\begin{array}{c}\text { Chlorophyll } \\
\text { concentration } \\
\text { at the chl max } \\
\left(\mu \mathrm{gl}^{-1}\right)\end{array}$ & $\begin{array}{c}\text { Maximum } \\
\text { hourly } \\
\text { ingestion rate } \\
\text { (ng ind }{ }^{-1} \mathrm{~h}^{-1} \text { ) }\end{array}$ & $\begin{array}{c}\text { Maximum } \\
\text { hourly } \\
\text { filtration rate } \\
\left(\mathrm{ml} \text { ind }^{-1} \mathrm{~h}^{-1}\right)\end{array}$ & $\begin{array}{l}\text { Minimum } \\
\text { hourly } \\
\text { ingestion rate } \\
\text { (ng ind } \mathrm{d}^{-1} \mathrm{~h}^{-1} \text { ) }\end{array}$ & $\begin{array}{c}\text { Minimum } \\
\text { hourly } \\
\text { filtration rate } \\
\left(\mathrm{ml} \text { ind }^{-1} \mathrm{~h}^{-1}\right)\end{array}$ & $\begin{array}{c}\text { Daily } \\
\text { ingestion } \\
\text { rate } \\
\text { (ng ind } \\
\left.\text { ind }^{-1} \mathrm{~d}^{-1}\right)\end{array}$ \\
\hline $12-13 \mathrm{Feb}$ & 3.54 & 0.34 & 0.10 & -0.11 & -0.03 & 2.1 \\
\hline $24-25 \mathrm{Mar}$ & 12.84 & 0.87 & 0.07 & 0.06 & 0.005 & 12.7 \\
\hline
\end{tabular}

Table 4. Species, stage distributions and average dry weights of copepods used in laboratory experiments

\begin{tabular}{|c|c|c|c|c|c|c|c|c|c|}
\hline \multirow[t]{2}{*}{ Date } & \multirow[t]{2}{*}{ Species } & \multicolumn{6}{|c|}{$\%$ composition } & \multirow{2}{*}{$\begin{array}{l}\text { Total number } \\
\quad\left(\text { ind } \mathrm{l}^{-1}\right)\end{array}$} & \multirow{2}{*}{$\begin{array}{c}\text { Average dry weight } \\
\left(\mu g \text { ind }^{-1}\right)\end{array}$} \\
\hline & & VIS & VI & Vq & $\mathrm{V} B$ & IV & III & & \\
\hline \multirow[t]{2}{*}{$5 \mathrm{Feb}$} & Pseudocalanus sp. & 27 & 5 & 12 & 25 & 21 & 10 & 692 & 7.8 \\
\hline & Acartia sp. & & & & & & & 72 & 3.6 \\
\hline \multirow[t]{2}{*}{$12 \mathrm{Mar}$} & Pseudocalanus sp. & 32 & 7 & 17 & 32 & 10 & 1 & 445 & 14.8 \\
\hline & Acartia sp. & & & & & & & 31 & 7.6 \\
\hline $14 \mathrm{Mar}$ & Pseudocalanus sp. & 28 & 5 & 28 & 23 & 16 & - & 160 & 14.6 \\
\hline
\end{tabular}


Table 5. Chlorophyli concentrations $\left(\mu \mathrm{g} \mathrm{l}^{-1}\right)$ in laboratory experiments. Results are expressed as the mean of the concentrations in the 3 carboys for each incubation $\pm \mathrm{SD}$

\begin{tabular}{|c|c|c|c|c|c|c|c|c|}
\hline \multirow[t]{2}{*}{ Date } & \multicolumn{2}{|c|}{ Incubation $\mathrm{A}$} & \multicolumn{2}{|c|}{ Incubation B } & \multicolumn{2}{|c|}{ Incubation $\mathrm{C}$} & \multicolumn{2}{|c|}{ Incubation D } \\
\hline & t-zero & t-final & t-zero & $t$-final & t-zero & $t$-final & t-zero & t-final \\
\hline 5 Feb & $17.82 \pm 0.64$ & $10.08 \pm 0.23$ & $16.79 \pm 0.54$ & $10.33 \pm 0.46$ & $21.80 \pm 0.18$ & $17.86 \pm 0.85$ & $22.22 \pm 0.84$ & $18.43 \pm 0.46$ \\
\hline $12 \mathrm{Mar}$ & $29.21 \pm 2.29$ & $30.37 \pm 0.36$ & $31.01 \pm 0.48$ & $29.74 \pm 1.02$ & $30.90 \pm 0.97$ & $30.26 \pm 1.63$ & $31.01 \pm 1.02$ & $31.53 \pm 0.66$ \\
\hline 14-15 Mar & $20.79 \pm 3.37$ & $19.15 \pm 0.48$ & $21.11 \pm 1.57$ & $20.11 \pm 1.57$ & $22.65 \pm 2.23$ & $20.74 \pm 1.43$ & $24.55 \pm 1.60$ & $21.80 \pm 0.18$ \\
\hline
\end{tabular}

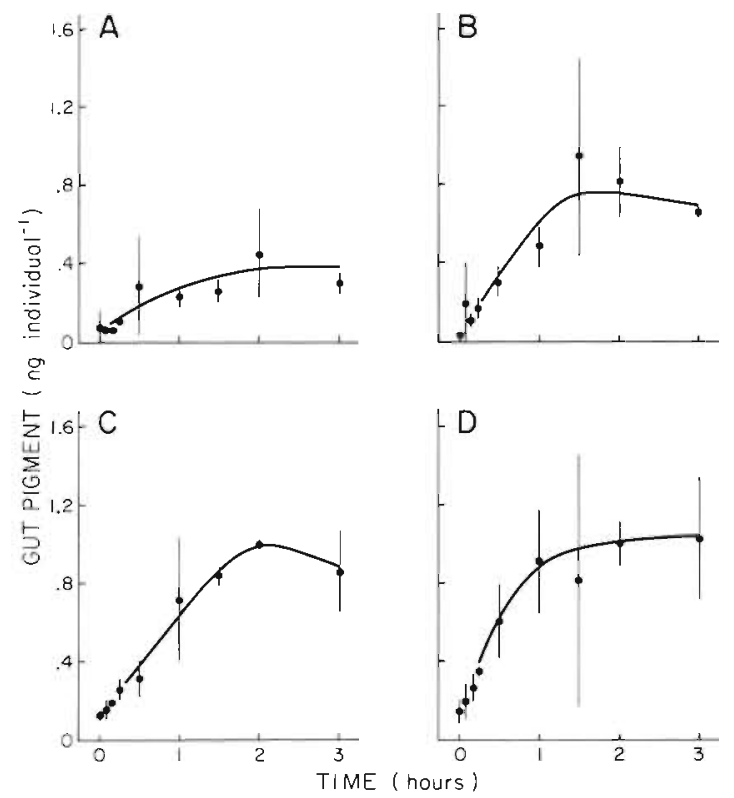

Fig. 5. Pseudocalanus sp. Time courses of the uptake of gut pigment (chlorophyll plus phaeopigment) on 5 Feb 1986. Points are the means of values obtained from 3 experimental carboys; standard deviations are shown as bars. Lines were drawn by eye. Incubation conditions were (A) daytime in the light; (B) daytime in the dark; (C) night-time in the light; (D) night-time in the dark

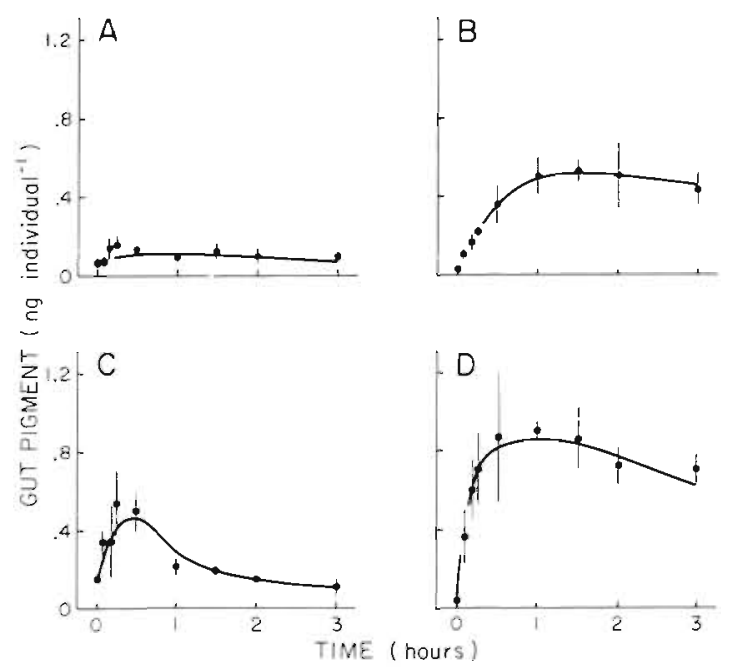

Fig. 6 Pseudocalanus sp. Time courses of the uptake of gut pigment (chlorophyll plus phaeopigment) on 12 Mar 1986. Presentation of data as in Fig. 5.
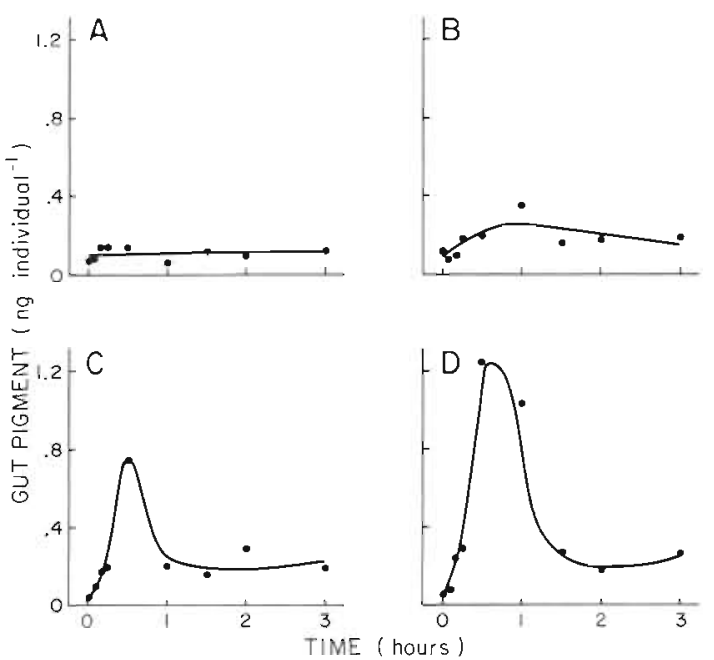

Fig. 7. Acartia sp. Time courses of the uptake of gut pigment (chlorophyll plus phaeopigment) on 12 Mar 1986. Presentation of data as in Fig. 5
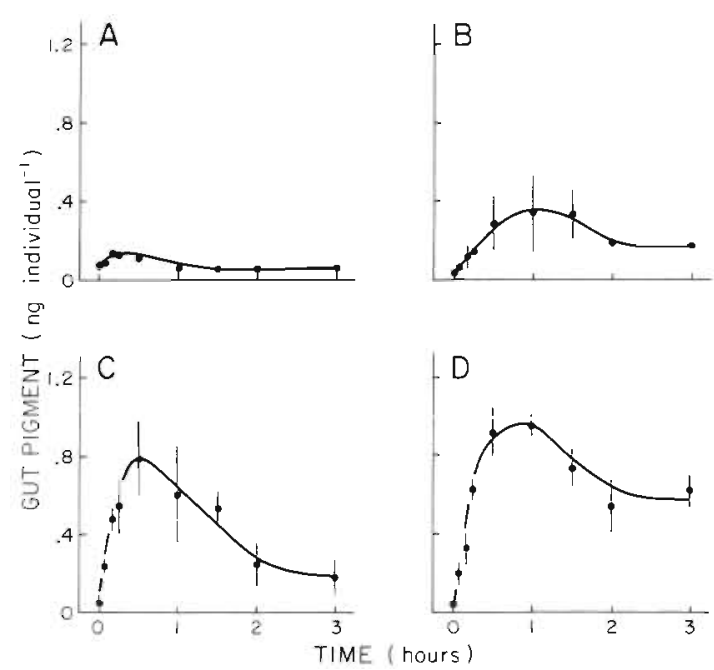

Fig. 8. Pseudocalanus sp. Time courses of the uptake of gut pigment (chlorophyll plus phaeopigment) on 14-15 Mar 1986. Points are the means of values obtained from 3 experimental carboys, standard deviations are shown as bars. Lines were drawn by eye. Incubation conditions were: (A) night-time in the light; $(B)$ night-time in the dark; (C) daytime in the light, (D) daytime in the dark 
time ones, initial rates of the night-time pair (A and $B$ ) and the daytime pair ( $C$ and $D$ ) were indistinguishable from each other. Equilibrium rates were all different at the $\mathrm{p}<0.05$ level, except that Incubation $\mathrm{B}$ was indistinguishable from Incubation $\mathrm{C}$.

The relative abundances of Pseudocalanus $\mathrm{sp}$. and Acartia sp. and the stage composition of the former in experiments performed in February were quite similar to those found during the diel sampling series (Tables 1 \& 4). For the March experiments the zooplankton composition resembled more closely that found in the early March diel series than that found during the 24-25 Mar series (Tables 1 \& 4).

\section{DISCUSSION}

For each of the diurnal series during the spring (Fig. 4 to 6) Pseudocalanus sp. and Acartia sp. exhibited similar feeding behaviors over each sampling period. In February they both showed variations in gut pigment content, but there was no indication of a diel component (Fig. 2). By contrast, in early March they both showed periods of elevated gut pigment content and ingestion rate, at dawn and dusk (Fig. 3). In late March, however, this pattern of behavior disappeared and both species appeared to be feeding more-or-less continuously again. Several authors have suggested that copepod feeding will be continuous at low food concentrations to enable the animals to maximize daily food intake (Bohrer 1980, Huntley \& Brooks 1982, Dagg 1985, Daro 1985), which may provide an explanation for the results obtained in February (Fig. 2) when diurnal feeding rhythms were absent and when the chlorophyll concentration was relatively low $1<4 \mu \mathrm{g}$ $1^{-1}$ ). The suggestion also fits the early March data set, where intermittent feeding was seen and the chlorophyll concentration was very high $\left(>20 \mu \mathrm{gl}^{-1}\right)$. It does not, however, fit the data for late March, where there were again no diurnal feeding patterns, despite quite high food concentrations $\left(>10 \mu \mathrm{g} \mathrm{l}^{-1}\right)$. One possible factor involved is suggested by the data for Pseudocalanus sp. in Tables $2 \& 3$. Even though the temperature differed by only $2 \mathrm{C}^{\circ}$ between the February and 24-25 Mar sampling dates, there was apparently a nearly 5-fold increase in defecation rate constant $\mathrm{k}$ (Table 2), if we use the value for February of $0.26 \mathrm{~h}^{-1}$, derived from the statistically better of the 2 February data sets. This suggests that copepods at the end of Mach could process food more rapidly than they had been able to in February. Maximum hourly filtration rates for Pseudocalanus sp., by contrast, did not change between the 2 dates (Table 3), which suggests that the maximum hourly ingestion rate over this period was dependent on food concentration. The inte- grated daily ingestion rate was much higher at the end of March than in early February and was perhaps controlled by an internal factor or digestive capacity. Now, if in the early March period the value of $\mathrm{k}$ was low, as in February, while the maximum hourly ingestion rate was high because of the very high food concentration, then it could be that discontinuous feeding at this time was the result of an imbalance between the capacities to ingest and digest food. According to Dagg \& Walser (1987) gut passage time, the inverse of $k$, in Neocalanus plumchrus increased at chlorophyll concentrations of $<4 \mu \mathrm{g} \mathrm{l}^{-1}$, and was constant above this level, which would suggest $\mathrm{k}$ should have been high in early March but there are several other factors which may have involved besides food concentration. For example it has been suggested that the value of $\mathrm{k}$ can vary with developmental stage (Kiørboe et al. 1985, Tande \& Båmstedt 1985). In Bedford Basin the stage distributions of Pseudocalanus sp. for the February and early March data sets were quite similar, so they might be expected to have had similar values for $k$, while by contrast the stage distribution in late March was somewhat different and may therefore have shown a different value. Another possibility is that $\mathrm{k}$ could be varying with food quality or composition (Nicolajsen et al. 1983, Head 1986). Carbon:chlorophyll and nitrogen:chlorophyll ratios in the top $10 \mathrm{~m}$ were different on each of the 3 spring sampling dates (Table 6). In February the relatively high values suggest that there was a large detrital component to the particulate material. In early March, however, the low values of these ratios were similar to those obtained in diatom cultures growing at a relatively high growth rate (Eppley \& Renger 1974 . Perry 1976) and suggest that most of the carbon was associated with phytoplankton. The intermediate values for 24 Mar and appearance of chlorophyll in the $<3$ $\mu \mathrm{m}$ fraction suggest that changes in perhaps both chemical and species composition had occurred during the bloom period. The effects of such changes on the value of $\mathrm{k}$ are not obvious. It might have either a high or low value for a food source of either high or low nutritional quality. For example, animals feeding on a low quality diet at a low concentration (February, perhaps) may assimilate more by keeping the food in the gut longer, while those feeding on a low quality diet at a high concentration (late March, perhaps) can perhaps do better by ingesting and defecating more rapidly and assimilating less efficiently. In this interpretation we assume that food quality was best during the early bloom period (early March) and that the copepod daily ration was easily assimilated then whether the value of $\mathrm{k}$ was in fact high or low. Evidence in favour of a changing digestibility of food has been presented by Bathmann \& Liebezeit (1986), who found that the chlorophyll and intact cell content of 
Table 6. Particulate chlorophyll, carbon and nitrogen concentrations in the top $10 \mathrm{~m}$ on 13 Feb, 3 Mar and 24 Mar 1986 . Data courtesy of $B$. Irwin

\begin{tabular}{|c|c|c|c|c|c|c|c|c|c|}
\hline Date & $\begin{array}{l}\text { Depth } \\
\text { (m) }\end{array}$ & $\begin{array}{l}\text { Chlorophyll a } \\
\text { conc. }\left(\mu g 1^{-1}\right)\end{array}$ & $\begin{array}{l}\text { POC conc } \\
\left(\mu \mathrm{gl}^{-1}\right)\end{array}$ & $\begin{array}{c}\text { PON conc. } \\
\left(\mu \mathrm{g} \mathrm{l}^{-1}\right)\end{array}$ & $\frac{\mathrm{POC}}{\mathrm{Chl} a}$ & $\frac{\text { PON }}{\text { Chl } a}$ & $\frac{\text { POC }}{\text { PON }}$ & $\begin{array}{l}\text { Chlorophyll a } \\
>3 \mu \mathrm{m}\left(\mu \mathrm{g} \mathrm{l}^{-1}\right)\end{array}$ & $\frac{\text { Chl } a \geq 3 u}{\text { Total chl } a}$ \\
\hline \multirow{3}{*}{13 Feb } & 1 & 1.90 & 216 & 34 & 114 & 18 & 6.4 & 0.89 & 0.47 \\
\hline & 5 & 2.39 & 272 & 45 & 114 & 19 & 6.0 & 1.13 & 0.47 \\
\hline & 10 & 2.51 & 253 & 44 & 101 & 18 & 5.8 & 1.28 & 0.51 \\
\hline \multirow{3}{*}{3 Mar } & 1 & 19.49 & 526 & 98 & 27 & 5 & 5.4 & 22.97 & $>1$ \\
\hline & 5 & 23.21 & 558 & 104 & 24 & 4 & 5.4 & 23.21 & 1.00 \\
\hline & 10 & 19.49 & 561 & 104 & 29 & 5 & 5.4 & 20.07 & $>1$ \\
\hline \multirow{3}{*}{$24 \mathrm{Mar}$} & 1 & 13.34 & 916 & 137 & 69 & 10 & 6.7 & 11.02 & 0.83 \\
\hline & 5 & 16.24 & 980 & 132 & 60 & 8 & 7.4 & 14.97 & 0.92 \\
\hline & 10 & 15.55 & 865 & 144 & 56 & 9 & 6.0 & 13.46 & 0.87 \\
\hline
\end{tabular}

Pseudocalanus fecal pellets, collected during a declining algal bloom, decreased dramatically over a $10 \mathrm{~d}$ period.

On the occasion when diurnal feeding rhythms were seen (Fig. 3) the cycles were reproducible on a day-today basis although the light intensity at which the evening onset of feeding began was higher than the threshold ( $\mathrm{ca}_{4} \mathrm{~W} \mathrm{~m}^{-2}$ ) suggested by Head et al. (1985) or the level (ca $2 \mathrm{~W} \mathrm{~m}^{-2}$ ) at which feeding rates decreased significantly in the data of Stearns (1986, Fig. 3). These discrepancies may be partially due to our lack of knowledge of the copepods' vertical distribution, which makes it impossible for us to know what light intensities they were actually experiencing, but clearly on neither occasion was light intensity the only factor involved. In fact the copepods seemed to feed for periods of only about $3 \mathrm{~h}$ in the early evening between approximately 1600 and $1900 \mathrm{~h}$. After this, gut content (Fig. 3) dropped to a lower level from about $2000 \mathrm{~h}$ until $0300 \mathrm{~h}$, before rising again with periods of increased feeding between about 0400 and $0900 \mathrm{~h}$ in the morning. Dawn and dusk or bimodal feeding patterns have been reported for Daphnia (Haney \& Hall 1975) and Calanus finmarchicus (Simard et al. 1985) and carn also be inferred in some instances for Temora longicornis, Centropages hamatus and C. finmarchicus (Baars \& Oosterhuis 1984) and for Acartia (Stearns 1986). It is possible that bimodal feeding patterns are in fact common, but the sampling frequencies required to demonstrate them ( 1 to $2 \mathrm{~h}$ ) have not often been used. In our data, as in that of Simard et al. (1985), the second feeding peak preceded the dawn light signal, which. led them to reject the suggestion (Haney \& Hall 1975) that changes in light intensity were responsible for the dawn increase in feeding rate. In their sampling situation they were looking at both feeding and vertical migration and were led to agree with the hungersatiation hypothesis (Conover 1968, Pearre 1973, 1979) in which animals migrate to the surface in the evening, feed, become sated, sink to depth while digesting and defecating, and then perform a second migration for a predawn meal. In our sampling series, vertical migration into and out of the top $30 \mathrm{~m}$ (early March) was not important although it is probable that satiation curtailed the evening feeding period.

In in situ studies such as those described here, the observed behavior patterns represent the summation of individual copepod behavior within the community. In the above discussion the behavior of individuals was assumed to be identical. Hence in early February and late March it was suggested that individuals fed continuously over the $24 \mathrm{~h}$ cycle. The behavior pattern observed in these population, however, could equally well have resulted from individual copepods feeding episodically, at random times of day and night, and it has been suggested that this is how they normally do feed (Cowles \& Strickler 1983, Mackas \& Burns 1986). If this is the case then the observed discontinuous feeding patterns in early March represent a period when these episodic feeding bouts were strongly synchronized, i.e. a period when the copepods were behaving similarly. If this is the case then the argument above concerning digestive ability may still hold but the question concerning discontinuous feeding has changed from one of why copepods should feed discontinuously at certain times to why they should exhibit synchronized feeding behaviors at these times.

Patterns of response to light and dark and day and night in the laboratory were variable (Fig. 5 to 7 ). In early March (Fig. $6 \& 7$ ), where natural food concentrations of close to $30 \mu \mathrm{kg}$ chl a $\mathrm{I}^{-1}$ were used, Pseudocalanus did not feed when exposed to light during the day and fed maximally in the dark at night. They would, however, feed during the day in the dark, while in the light at night they were inhibited from feeding, after a short (ca $1 / 2 h$ ) burst of activity. Similar results were obtained in Calanus glacialis (Head 1986) and Calanus hyperboreus (Head unpubl. data). In early 
March Acartia sp. did not feed during the day in the light and fed maximally at night in the dark (Fig. 7). The duration of the night-time feeding activity period was, however, only about $1 \mathrm{~h}$ in contrast to that for Pseudocalanus, where the feeding activity level remained high throughout the $3 \mathrm{~h}$ incubation. In addition Acartia did not feed in the dark during the daytime, in contrast to Pseudocalanus, although at night in the light their behaviors were similar. In both species light intensity had a direct effect on feeding activity, as has also been shown by Head (1986) and Stearns (1986). When Pseudocalanus sp. were collected in the aftermoon and experiments run that evening and the following morning, a different pattern of behavior was observed (Fig. 6). These results suggest that it is not possible to divorce the effect of time of day from the effect of previous feeding history. Night-time feeding rates in this case were close to daytime rates observed in copepods collected mid-morning (cf. Fig. 6A, B and Fig. $8 \mathrm{~A}, \mathrm{~B})$. Hence it is possible that night-time in vitro rates in copepods collected mid-morning were higher than daytime in vitro rates because of a hunger response (Runge 1980), although in fact even nighttime ingestion rates in vitro were not as high as those expected in situ, since in the March experiments the copepods never achieved the gut pigment levels observed in situ. One obvious in vitro effect, however, is that the inhibition of feeding by light is increasingly reduced, especially as regards the short-term response, the longer copepods have spent without food. The results obtained in vitro in early March are consistent with the observed in situ behavior pattern described earlier, if the evening onset of feeding is triggered by a decrease in light intensity, the midnight diminution in feeding rate is the result of satiation, and the predawn feeding period is terminated by either light or satiation.

In February, natural phytoplankton could not be used, because its concentration was so low that it would have been seriously depleted during the course of laboratory experiments. Consequently, a culture of Chaetoceros gracilis was used at higher than in situ concentrations. In this case the feeding rate of Pseudocalanus sp. in the light in the day was lower than in all 3 other incubations, even if allowances were made for the slightly different chlorophyll concentrations that occurred in the daytime and night-time incubations (Table 5). The daytime results are perhaps surprising in view of the in situ results which showed no daytime decrease in gut content (Fig. 2), but the night-time lack of response may represent a hunger response as discusssed above, perhaps of a longer duration.

On the basis of results presented here and elsewhere (Hayward 1980) it seems as though the following generalisations can be made. Firstly, intermittent, diur- nal or bimodal feeding activities may be seen under conditions of either high or low in situ food concentrations even when copepods do not vertically migrate. Secondly, continuous feeding activity may also occur at either high or low in situ food concentration. Thirdly, light intensity has a direct effect on feeding activity which appears to be most marked in copepods which have recently fed. Finally, although the evening onset of feeding in diurnally feeding copepods coincides with, and probably results from, the evening decrease in light intensity, satiation may cause copepods to stop feeding before the end of the night-time period. Diurnal feeding behavior patterns of copepods in situ are probably influenced by a number of factors which include internal effects due to physiological state, metabolic requirements, previous feeding history and vertical migratory behavior and external factors such as food concentration and composition and light intensity. The relative importance of each of these stimuli will be different in different situations, and an understanding of diel feeding rhythms will probably only come from studies in which all of these facors are examined at the same time

Acknowledgements. The authors thank Ms P. Hunter and Ms C. Frazer for help in analysing the samples. They are also grateful to Dr R. J. Conover for lengthy and stimulating discussions during the preparation of this manuscript.

\section{LITERATURE CITED}

Baars, M. A., Oosterhuis, S. S. (1984). Diurnal feeding rhythms in North Sea copepods measured by gut fluorescence, digestive enzyme activity and grazing on labelled food. Neth. J. Sea. Res. 18: 97-119

Banse, K. (1964). On the vertical distribution of zooplankton in the sea. Prog. Oceanogr. 2: 53-125

Bathmann, U., Liebezeit, G. (1986). Chlorophyll in copepod faecal pellets: changes in pellet numbers and pigment content during a declining Baltic Spring bloom. P. S. Z. N. I. Mar. Ecol. 7: 59-73

Bohrer, R. (1980). Experimental studies on diel vertical migration. In: Kerfoot, W. C. (ed.) Evolution and ecology of zooplankton communities. University Press, London, p. 111-121

Boyd, C. M., Smith, S. L., Cowles, T. J. (1980). Grazing patterns of copepods in the upwelling system off Peru. Limnol. Oceanogr. 25: 583-596

Conover, R. J. (1968). Zooplankton-life in a nutritionally dilute environment. Am. Zool. 8: 107-118

Cowles, T. J., Strickler, J. R. (1983). Characterization of feeding activity patterns in the planktonic copepod Centropages typicus Kroyer under various food conditions. Limnol. Oceanogr. 28: 106-115

Cushing, D. H. (1951). The vertical migration of planktonic organisms. Biol. Rev. 26: 158-192

Dagg, M. J. (1985). The effects of food limitation on diel migratory behavior in marine zooplankton. Arch. Hydrobiol Beih. Ergebn. Limnol. 21. 247-255 
Dagg, M. J., Wymann., K. D. (1983). Natural ingestion rates of the copepods Neocalanus plumchrus and $N$. cristatus calculated from gut contents. Mar Ecol. Prog. Ser. 13: 37-46

Dagg, M. J., Walser, W. E., Jr. (1987). Ingestion, gut passage, and egestion by the copepod Neocalanus plumchrus in the laboratory and in the subarctic Pacific Ocean. Limnol. Oceanogr. 32: 178-188

Daro, M. H. (1980). Field study of the diel feeding of a population of Calanus finmarchicus at the end of a phytoplankton bloom, FLEX 76, 22 May-5 June. 'Meteor' Forsch.-Ergebnisse A. 22: 123-132

Daro, M. H. (1985). Feeding rhythms and vertical distribution of marine copepods. Bull. mar Sci. 37: 487-497

Eppley, R. W., Renger, E. H. (1974). Particulate organic matter flux and planktonic new production in Southern California Coastal waters. J. Phycol. 10: 15-23

Fancett, M. S., Kimmerer, W. J. (1985). Vertical migration of the demersal copepod Pseudodiaptomus as a means of predator avoidance. J. exp. mar. Biol. Ecol. 88: 31-43

Gauld, D. T. (1953). Diurnal variation in the grazing of planktonic copepods. J. mar. biol. Ass. U. K. 31, 461-474

Gliwicz, M. Z. (1986). Predation and the evolution of vertical migration in zooplankton. Nature, Lond. 320: 746-748

Haney, J. F., Hall, D. J. (1975). Diel vertical migration and filter feeding activities of Daphnia. Arch. Hydrobiol. 75: 413-441

Hardy, A. C., Bainbridge, R. (1954). Experimental observations on the vertical migrations of plankton animals. J. mar biol. Ass. U. K. 33: 409-448

Hayward, T. L. (1980). Spatial and temporal feeding patterns of copepods from the North Pacific Gyre. Mar. Biol. 58: 295-309

Head, E. J. H. (1986). Estimation of Arctic copepod grazing rates in vivo and comparison with in vitro methods. Mar. Biol. 92: 371-380

Head, E. J. H., Harris, L. R., Abou Debs, C. (1985). Effect of daylength and food concentration on in situ diumal feeding rhythms in Arctic copepods. Mar. Ecol. Prog. Ser. 24 281-288

Holm-Hansen, O., Lorenzen, C. J., Holmes, R. W., Strickland J. D. H. (1965). Fluorimetric determination of chlorophyll J. Cons. int. Explor. Mer 30: 3-15

Huntley, M., Brooks, E. R. (1982). Effects of age and food availability on diel vertical migration of Calanus pacificus. Mar. Biol. 71. 23-31

Kiørboe, T., Tiselius, P. T (1987). Gut clearance and pigment destruction in a herbivorous coped, Acartia tonsa, and the determination of in situ grazing rates. J. Plankton Res. 9 $525-534$

Kiøoboe, T., Møhlenberg, F., Ruisgārd, H. U. (1985). In situ feeding rates of planktonic copepods: a comparison of fout methods. J. exp. mar Biol. Ecol. 88: 67-81

Lampert, W., Taylor, B. E. (1985). Zooplankton grazing in a eutrophic lake: implications of diel vertical migration. Ecology 66: 68-82
Longhurst, A. R. (1985). Relationship between diversity and vertical structure of the upper ocean. Deep Sea Res. A 32: $1535-1570$

Mackas, D. L., Bohrer, R. (1976). Fluorescence analysis of zooplankton gut contents and investigation of diel feeding patterns. J. exp. mar. Biol. Ecol. 25: 77-85

Mackas, D. L., Burns, K. E. (1986). Post-starvation feeding and swimming activity in Calanus pacificus and Metridia pacifica. Limnol. Oceanogr. 31. 383-392

Mayzaud, O., Mayzaud, P., de la Bigne, C., Grohan, P. (1984). Diel changes in the particulate feeding activity and digestive enzyme concentration in neritic zooplankton. J. exp. mar. Biol. Ecol. 84: 15-35

McAllister, C. D. (1970). Zooplankton rations, phytoplankton mortality and the estimation of marine production. In: Steele, J. H. (ed.) Marine food chains. Oliver and Boyd, Edinburgh, p. 419-457

McLaren, I. A. (1963). Effects of temperature on growth of zooplankton and the adaptive value of vertical migration. J. Fish. Res. Bd Can. 20: 685-727

Nicolajsen, H., Molenberg, F., Kiørboe, T. (1983). Algal grazing by the planktonic copepods Centropages hamatus and Pseudocalanus sp. Diumal and seasonal variation during the spring phytoplankton bloom in the Øresund. Ophelia 22: $15-31$

Pearre, S. (1973). Vertical migration and feeding in Sagitta elegans Verrill. Ecology 54: 300-314.

Pearre, S. (1979). Problems of detection and interpretation of vertical migration. J. Plankton Res. 1: 29-44

Perry, M. J. (1976). Phosphate utilization of an oceanic diatom in phosphorus limited chemostat culture and in oligotrophic waters of the Central North Pacific. Limnol. Oceanogr 21: 88-107

Runge, J. A. (1980). Effects of hunger and season. on the feeding behavior of Calanus pacificus. Limnol. Oceanogr 25: $134-145$

Simard, Y., Lacroix, G., Legendre, L. (1985). In situ twilight grazing rhythm during diel vertical migrations of a scattering layer of Calanus finmarchicus. Limnol. Oceanogr 30: 598-606

Stearns, D. E. (1986). Copepod grazing behavior in simulated natural light and its relation to nocturnal feeding. Mar. Ecol. Prog. Ser. 30: 65-76

Stearns, D. E., Forward, R. B., Jr (1984). Copepod photobehavior in a simulated natural light environment and its relations to nocturnal vertical migration. Mar. Biol. 82: $91-100$

Tande, K. S., Bamstedt, U. (1985). Grazing rates of the copepods Calanus glacialis and C. finmarchicus in arctic waters of the Barents Sea. Mar Biol. 87.251-258

Williams, R. Conway, D. V P. (1984). Vertical distribution, and seasonal and diurnal migration on Calanus helgolandicus in the Celtic Sea. Mar Biol. 79: 63-73

Zaret, T. M., Suffern, J.S. (1976). Vertical migration as a predator avoidance mechanism. Limnol. Oceanogr. 21 $804-813$ 